\title{
Redaktionelt forord
}

- Demokrati og offentlighed

"Demokratiet er det forhold, at lovgiverne selv er underkastet loven, og at ingen er underkastet loven uden selv at være lovgiver". Således definerer Andreas Beck Holm demokratiet i dette nummer af SLAGMARK med temaet Demokrati og Offentlighed. En bestemmelse af demokratiet har været objekt for forskningsmæssig diskussion siden begrebets genkomst som moderne politisk begreb i 1700-tallet, hvor oplysningsfilosoffer som Jean-Jacques Rousseau, der har inspireret ovenstående definition, tog begrebet $\mathrm{i}$ anvendelse. Hvad vi forstår ved demokrati, og hvordan dets demos - folket skal bestemmes og regere, er et tilbagevendende tema for politisk forskning. I dag, hvor demokratibegrebet anvendes i en mængde betydninger, og hvor dets betydningsindhold derfor kun vanskeligt lader sig indkapsle, synes forskning i demokrati som idé, begreb og praksis fortsat relevant.

Demokrati betegner i dag noget, kun de færreste vil erklære sig som modstandere af, men som man ofte ser anvendt om positioner, man ønsker at kritisere - her karakteriseret som udemokratiske. Netop fordi begrebet anvendes fra snart sagt alle politiske positioner og i et væld af forskelligartede betydninger, bliver det vanskeligt at nærme sig en eksakt definition af begrebet, så snart man ønsker at bevæge sig en smule videre fra ordets etymologi.

Hos Beck Holm bestemmes demokratiet som et forhold mellem lov, lovgivere og underkastelse, hvor demokratiet synes at implicere et fravær af eksklusion. Følger man denne definition vil man kunne spørge, om nogle af de fra historien kendte demokratier kan karakteriseres som værende 'sande' demokratier - med andre ord, om vi kender eksempler på samfund, hvor ingen er underkastet loven uden selv at være lovgiver?

Dette leder til spørgsmålet, om demokratiet overhovedet er eller kan være demokratisk? Kan man tænke sig en styreform, som lever 
op til ordets etymologiske betydning, folke-styre? Typisk vil en behandling af demokratiet som begreb og idé lægge ud med en konstatering af netop den etymologiske betydning af begrebet fulgt af den konstatering, at en medfødt problemstilling i ethvert erklæret demokrati vil være bestemmelsen af demos, altså hvem 'folket' inkluderer. Historien om vort demokrati er da også en historie om, hvordan forskellige grupper og individer har kæmpet om retten til politisk inklusion, herunder at opnå en plads i den politiske offentlighed, en historie som også flere artikler i nærværende nummer skriver sig ind $i$.

Demokratibegrebet har i hele dets moderne historie været omstridt. Reinhart Koselleck betegnede i 1972 demokratibegrebet som et alment overbegreb, der har fortrængt alle andre forfatningstyper som illegitime. Dette som kulmination på en udvikling fra oprindeligt at være et antikt forfatningslærebegreb, over en aktualisering af begrebet i det 18. århundrede til demokratiets forvandling til forventningsbegreb i forbindelse med de store politiske revolutioner i det lange 19. århundrede. Især efter 2. verdenskrig er demokratiet blevet alment anerkendt som 'den bedste' styreform; det er et begreb, som langt de fleste bekender sig til, og det er en betegnelse, hvis ubetinget positive konnotationer gør begrebet attraktivt at tilegne sig. Hermed er tidligere kampe for og imod demokratiet hvilke har præget det meste af begrebets moderne historie - i høj grad blevet erstattet af kampe med demokratiet, som fx genkendes på argumentationsformen: "Vi har demokratiet på vores side".

Demokrati er imidlertid ikke kun en betegnelse for en styreform. I dag opfatter en af de mest indflydelsesrige demokratiteoretiske skoler demokrati som en samfundsform, hvor borgernes lige ret til indgåen i den offentlige samtale er dét, som udgør demokratiet. Denne position kendes især fra traditionen for deliberativt demokrati, som flere af artiklerne i dette nummer af SLAGMARK forholder sig enten affirmativt eller kritisk til.

Den deliberative demokratimodel - som inden for de seneste år har fået en del bevågenhed i forskningen - forbindes især med den tyske filosof og sociolog Jürgen Habermas og hans forsøg på at bygge bro mellem den liberalistiske samfundsmodels friheds- og rettighedsfokuserede (men tendentielt individualistiske) offentlighedsforståelse og den republikanske models fokus på statsborger- 
nes interesser og fælles mål, der potentielt set geråder i konflikt og konsensuelt kaos. Ifølge Habermas træder en deliberativ forestilling om politik som rationel problemløsning ind på scenen som moderator - og ikke mindst som en kritisk doktrin om, at politiske beslutninger kun kan vinde legitimitet ved at blive diskuteret offentligt af rationelle borgere. Deliberationen tjener således et dobbelt formål; den både påvirker og kontrollerer (og derved legitimerer) det politiske system og de administrative beslutninger. En vigtig pointe er, at effekterne af den deliberative proces imidlertid ikke kun begrænser sig til indflydelsen på de rent lovgivningsmæssige processer, men i høj grad påvirker niveauet af tilgængelig oplysning og information, som er en grundbetingelse for borgernes faktiske politiske deltagelse i samfundet.

Som deltagelsesdemokratisk ideal har ideen om en debatterende politisk offentlighed imidlertid idéhistoriske rødder, der går længere tilbage end Habermas. Et vigtigt nedslag kunne - som Christinas Fiig påpeger $\mathrm{i}$ sit bidrag til dette nummer - laves hos John Stuart Mill og dennes ideer om emancipation og lige rettigheder og ikke mindst forestillingen om, at politisk deltagelse i sig selv virker fremmende for borgernes intellektuelle evner, dannelse og praktiske foretagsomhed. En tankegang, der går igen i John Deweys direkte kobling mellem demokrati og uddannelse, hvor demokrati opfattes som en særlig livsform, hvis mulighedsbetingelse afhænger af borgernes daglige samvirke og ikke mindst tro på at konflikter og kontroverser kan håndteres i en vedvarende dialog, der medinddrager erfaringsprocesserne. Vender vi blikket mod vores hjemlige tradition, dukker navnet Hal Koch uvægerligt op som et eksempel på en tænker, der opfatter netop samtale, deltagelse og medborgerskab som demokratiets livsnerve. I bogen Hvad er demokrati? fra 1945 møder vi ideen om demokrati som en livsform, dvs. som en bestemt måde at interagere på som mennesker, der udelukker vold og tvang, og som har samtalen og den gensidige respekt som sin altafgørende forudsætning.

Som Benjamin Ask Popp-Madsen i en anden af nummerets artikler bemærker, har den deliberative tænkning de seneste år medført en række demokratiteoretiske knopskydninger og nye teoridannelser. Madsen nævner Seyla Benhabib og Joshua Cohens arbejde med teoretiske og institutionelle problematikker knyttet til 
et civilsamfundsfokuseret deltagelsesdemokrati eller Benjamin Barbers begreb om det 'stærke' demokrati. I forlængelse heraf bør også nævnes den feministiske traditions kritik og videreudvikling af Habermas' model - fx i form af Nancy Frasers begreb om alternative deloffentligheder, hvis betydning strækker sig ud over beslutningstagning på parlamentarisk niveau, og snarere udgør en ramme om brede, decentrale politiske diskussioner, der omhandler kulturelle og hverdagslige problematikker, og således udvider hele det politiske felt.

Med til denne skitsering hører selvfølgelig også den kritik som den deliberative model har været og aktuelt er udsat for. Politiske teoridannelser fra såvel højre som venstre har ud fra en række parametre påpeget modellens fallit og kommen til kort $\mathrm{i}$ en kompleks politisk virkelighed, hvor deliberationen i bedste fald har marginal betydning, i værste fald bygger på en misvisende og utopisk forestilling om en konsensus, som fortrænger magtudøvelsesaspektet i det politiske. Selv det deliberative demokrati er repressivt, når magten sætter sig igennem - som Andreas Beck Holm i sin artikel på baggrund af Jacques Rancières demokratikritik argumenterer for. Desuden bliver spørgsmålet om inklusion/ eksklusion her relevant i forhold til hvilke befolkningsgrupper, der rent faktisk har - og historisk set har haft - adgang til offentligheden.

Hvorom alting er: Den demokratiske offentlige dialog synes $i$ dag at være under pres fra en række forskellige kanter: fænomener som politisk spin, professionalisering, personalisering, globale virksomheders kapitalistiske ekspansion, kommercialisering og lobbyisme truer ifølge en række demokratiteoretikere den demokratiske offentligheds mulighed for at danne ramme om de politiske beslutningsprocesser og den dialog, der skaber en aktiv politisk kultur. Ikke mindst bærer disse fænomener ved til den omsiggribende 'politikerlede', som opstår når mulighedsbetingelserne for aktiv og autentisk deltagelse ser ud til at smuldre.

Med SLAGMARK nr. 69 ønsker vi at bidrage til udforskningen af demokratiet som idé, begreb og praksis med bidrag som tematiserer demokratiet fra en række forskellige positioner og med udgangspunkt i forskellige fagligheder.

Udvalget af artikler grupperer sig inden for tre overordnede tematiske rammer; en teoretisk-filosofisk, en historisk og endelig en 
mere case-baseret, der inden for en idéhistorisk-filosofisk ramme afsøger fænomener eller begreber, der knytter sig til demokrati- og offentlighedsbegrebet.

Andreas Beck Holm stiller i artiklen "Demokrati og legitimitet: Rancière og kritikken af deliberativt demokrati" det vanskelige, men centrale spørgsmål: Hvori består den demokratiske styreforms legitimitet? Demokratiet er selvlegitimerende i sin egen konsensusorienterede selvforståelse, men - som Beck Holm påpeger - skjuler samtidig, at den som politisk styreform baserer sig på magtudøvelse og derfor rummer et grundlæggende element af illegitimitet. Konsensus er dermed kun tilsyneladende - snarere er den tro på fornuften, der ligger til grund for det deliberative demokrati i sig selv repressiv, i det den udelukker ikke-liberale, anderledes tænkende fra den universelle fornufts politiske fællesskab.

Benjamin Ask Popp-Madsens bidrag "Debatterende eller besluttende offentlighed?" fortsætter kritikken af den deliberative demokratimodel og Habermas' offentlighedsopfattelse. Gennem en læsning af Schmitt og Arendt fremsættes begrebet om den konstituerende magt og offentlighed som et alternativ til en debatterende offentlighed ud fra ideen om folket som beslutningsdygtigt og decentralt konstituerende i offentlige råd.

I "Fenrisulven sluppet løs" kortlægger Bertel Nygaard, N.F.S. Grundtvigs kritik af demokratiet gennem en analyse af det politiske skrift Politiske Betragtninger med Blik paa Danmark og Holsteen fra 183031. Grundtvigs forståelse af demokrati som et revolutionært og ugudeligt princip læses af Nygaard som et udtryk for det, Jacques Rancière har betegnet som et 'had til demokratiet'. Gennem en analyse af demokratibegrebets relation til andre grundbegreber, samt en påvisning af indre modsætninger i teksten, argumenterer Nygaard for, at Grundtvigs demokratikritik var iøjnefaldende eksplicit og radikal for sin samtid. Hermed bidrager artiklen til en nuancering af opfattelsen af Grundtvig som en ærkedemokratisk stamfader til det danske politiske system.

Anne Engelst Nørgaard undersøger i bidraget "Hvoraf kommer det, at vi alle ere saa demokratiske som vi ere" retorik og begrebsbrug hos den første organiserede bondebevægelse i Danmark i 1849. Gennem en undersøgelse af bevægelsens begrebsbrug argumenterer Engelst Nørgaard for, at Bondevennernes Selskab søgte 
at legitimere et krav om en demokratisk forfatning med den absolutistiske kongefigur, hvormed demokratibegrebet knyttedes til monarkiske idealer. Dette betegnes som et tidligt eksempel på en begrebslig kobling mellem demokrati og monarki. Med henvisning til enevældens ligestilling af rigets undersåtter under kongen, kunne Bondevennernes Selskab legitimere bøndernes krav om lige inkludering i borgerfællesskabet.

I "Folkhemmets demokrati" undersøger Anna Friberg, hvordan det svenske demokratibegreb udvikledes i sprogbrugen hos Sveriges socialdemokratiska arbetareparti i 1920erne i tiden efter indførslen af den almindelige og lige stemmeret. Heri vises det, at demokratibegrebet for SAP var mere end et begreb for en styreform, og at det anvendtes om forskellige samfundsforhold. Således anvendtes 'industrielt demokrati' $i$ argumenter for at arbejderne skulle styre industrien, mens 'økonomisk demokrati' indeholdt krav om en mere ligelig fordeling af økonomisk magt. Friberg konkluderer, at en indbygget konflikt mellem SAPs ideologiske socialisme og grundlæggende princip om demokrati medførte, at en demokratisering af samfundet for SAP forblev et igangværende og udefinerbart projekt.

Stig Thøgersen har i artiklen " Politisk deltagelse under autoritær kontrol" undersøgt, hvordan en kinesisk model for konsultativt demokrati søges implementeret, samt hvilken demokratiforståelse denne bygger på. Konsultativt demokrati anvendes som betegnelse for en politisk model, hvor en styret politisk deltagelse fx i form af konsultationer erstatter valg. Thøgersen forklarer, hvilke udfordringer denne model står overfor, bl.a. qua en spirende internetbaseret offentlighed. Han konkluderer, at på trods af initiativer til større inddragelse af kinesiske borgere, forbliver betegnelsen 'konsultativt demokrati' primært et ord, som myndighederne smykker sig med uden at leve op til det.

Artiklen "Valgretsdebattens vitale stemmer" af Christina Fiig giver et fascinerede indblik i sidste fase af den danske valgretskamp (1908-1915), hvor Landsforbundet for Kvinders Valgret kæmpede for at sikre kvindernes parlamentariske valgret. Med afsæt i en Habermasiansk, feministisk udfoldet offentlighedsteori argumenterer Fiig for, at deltagelse i en offentlig debat per se rummer demokratiske potentialer, idet offentligheden udgør en vigtig arena for læring, 
for kollektiv problemidentifikation og for artikulation af politiske identiteter. I valgretskampen bliver køn således for første gang en socialt relevant kategori i det politiske liv.

I artiklen "Whistleblower-ordninger: Offentlighed, kritik og risikohåndtering" undersøger Erik Mygind du Plessis fænomenet Whistleblowing $i$ en dansk og international kontekst. Artiklen skitserer fænomenets opkomst, og den klassiske forståelse af begrebet, som derefter sættes i relation til de såkaldte whistleblowerordningerne og den moderne fortolkning af begrebet, der følger med disse. Det analyseres, hvordan begrebet whistleblowing giver anledning til en række divergerende fortolkninger af offentlighedens rolle, lige såvel som der argumenteres for, at den stigende brug af whistleblower-ordninger synes at indvarsle en ny betydning af selve begrebet whistleblowing i en organisatorisk kontekst.

Mikkel Thorup analyserer i sin artikel "'Sandheden vil sætte os fri" - konspirationsteori som demokratisk praksis" konspirationsteorier som en særlig form for magtkritik og demokratisk argumentation i lyset af de ændringer i demokratiets idé og praksis, der er sket gennem de seneste årtier. Ifølge Thorup kan disse ændringer sammenfattes under begrebet transparens, nemlig troen på at det sande demokrati vil indfinde sig, hvis blot alt er gennemlyst, sandheden kommer for en dag, og befolkningen får tingenes rette sammenhæng at vide. I den forstand kan konspirations- og transparensteorier opfattes som magtkritik og som en modmagtsdiskurs, der på den ene side trækker på demokratiske idealer, men som samtidig udgør symptomer på demokratiets aktuelle tilstand og forskydning $\mathrm{i}$ retning af et tilsyns-demokrati.

I Luise Li Langergaards artikel "Skal den offentlige sektor være innovativ?" udfoldes en kritisk analyse og diskussion af innovation som forandringsbegreb i den offentlige sektor på baggrund af de dominerende forståelser af innovation, som findes i forskningslitteraturen og i politiske strategipapirer. Langergaard argumenterer for, at de eksisterende begreber om innovation nedtoner de særligt offentlige og demokratiske dimensioner ved den offentlige sektor, og at det er problematisk fra et demokratisk synspunkt. Hun opfordrer derfor til, at vi gentænker innovationsbegrebet på en måde, der kan gøre op med arven fra det økonomiske innovationsbegreb, og at vi i stedet formulerer en innovationsteori med 
politisk filosofiske begreber som rettigheder, retssikkerhed og demokrati i fokus.

SLAGMARKS debatsektion indeholder denne gang et essay om den tyske forfatter og enfant terrible, Botho Strauß' seneste essay Der Plurimi-Faktor, samt et essay om overvågningsdebatterne i kølvandet på Edward Snowdens afsløringer.

SLAGMARK afsluttes som vanligt med en anmeldersektion, hvor nyere udgivelser med idéhistorisk og filosofisk relevans gives en kritisk omtale.

Tilbage er der kun at ønske rigtig god læselyst.

På vegne af redaktionen

Anne Engelst Nørgaard

Rikke Alberg Peters 